\title{
OPTIMALISASI PERAN KADER MENGGUNAKAN PEER GROUP EDUCATION DALAM MENINGKATKAN CAKUPAN VAKSINASI COVID-19.
}

\author{
Pipit Festi Wilianarti'1), Yuanita Wulandari ${ }^{2)}$ \\ 1)Departemen Keperawatan Komunitas dan Keluarga, Fakultas IImu Kesehatan Universitas Muhammadiyah Surabaya \\ 2)Departemen Keperawatan Maternitas dan Anak, Fakultas IImu Kesehatan Universitas Muhammadiyah Surabaya \\ Corespodensi Athur: Pipit Festi Wilianarti \\ E-mail:pipitfesti@fik-umsurabya.ac.id
}

Diterima 30 Juli 2021, Direvisi 06 Agustus 2021, Disetujui 06 Agustus 2021

\begin{abstract}
ABSTRAK
Tingginya kejadian COVID-19 pada kelompok lanjut usia merupakan suatu masalah kesehatan di seluruh Dunia. Kurangnya pengetahuan masyarakat tentang pencegahan penularan COVID-19 dan perilaku tidak mentaati protokol kesehatan sangat berisiko kepada status kesehatan masyarakat. Antisipasi untuk menurunkan angka kejadian COVID-19 dilaksanakan pemerintah dengan memberikan vaksinasi pada kelompok resiko tinggi. Kondisi yang terjadi adanya banyak kelompok resiko yang kurang memiliki pengetahuan sehingga tidak bersedia untuk melaksanakan vaksinasi. Hal ini akan berdampak pada tingginya resiko penularan COVID-19. Sosialisasi yang telah dilaksanakan kurang maksimal mencapai target sasaran. Sehingga dibutuhkan metode yang tepat sehingga kader kesehatan dapat melaksanakan tugas dan peran dalam meningkatkan cakupan vaksinasi COVID-19. Tujuan dari penulisan ini adalah memberikan gambaran tentang pelaksanaan pengabdian pada kelompok Kader Kesehatan di Wilayah Kecamatan Mulyorejo untuk meningkatkan cakupan vaksianasi di masa pandemic COVID-19. Diharapkan masyarakat khususnya yang berisiko tinggi dalam penularan COVID19 mempunyai pengetahuan tentang pentingnya vaksinasi. Sehingga timbul kesadaran diri untuk bersedia melakukan vaksinasi sebagai upaya pencegahan penularan COVID-19. Kesadaran diri akan meningkatkan cakupan vaksinasi pada kelompok resiko khususnya lanjut usia.
\end{abstract}

Katakunci: pandemi; COVID-19; vaksinasi; peran kader; peer group education.

\begin{abstract}
The high incidence of COVID-19 in the elderly is a health problem worldwide. The lack of public knowledge about preventing the transmission of COVID-19 and the behavior of not complying with health protocols are very risky to public health status. Anticipation to reduce the incidence of COVID-19 is carried out by the government by providing vaccinations for high-risk groups. The condition that occurs is that there are many risk groups who lack knowledge so they are not willing to carry out vaccinations. This will have an impact on the high risk of transmission of COVID-19. The socialization that has been carried out has not reached the maximum target. We need the right method which health cadres can carry out their duties and roles in increasing COVID-19 vaccination coverage. The purpose of this paper is to provide an overview of the implementation of service to the Health Cadre group in the Mulyorejo District Area to increase vaccination coverage during the COVID-19 pandemic. It is hoped that the public, especially those at high risk of transmitting COVID-19, have knowledge about the importance of vaccination. Therefore, self-awareness arises to be willing to vaccinate as an effort to prevent the transmission of COVID-19. Self-awareness will increase vaccination coverage in risk groups, especially the elderly.
\end{abstract}

Keywords: pandemic; COVID-19; vaccination; role of cadre; peer group education.

\section{PENDAHULUAN}

Lanjut usia merupakan kelompok yang paling rentan terkena dampak penyakit COVID19. Data dari World Health Organization menunjukkan lanjut usia lebih banyak mengalami infeksi virus corona yang berdampak infeksi berat dan kematian dibandingkan pada balita. Jumlah kematian di China pada populasi usia 60-69 tahun sebesar
3.6 persen, pada usia $70-79$ tahun sebesar 8 persen dan pada usia lebih dari 80 tahun sebanyak 14.8 ( World Health Organization Organization \& Centers for Disease Control, 2020). Di Indonesia, dimana angka mortalitasnya meningkat seiring dengan meningkatnya usia yaitu pada populasi usia 4554 tahun adalah 8 persen, 55-64 tahun 14 persen dan 65 tahun ke atas 22 persen. 
Kerentanan lanjut usia pada pandemi COVID19 disebabkan penurunan daya tahan akibat degenerasi dan penyakit komorbid pada lanjut usia yang akan meningkatkan risiko kematian. Selain itu, dampak COVID-19 pada lanjut usia yaitu menimbulkan dampak fisik dan psikologis (Indarwati, 2020). Dimana prognosis lanjut usia yang terinfeksi COVID-19 lebih buruk dibandingkan dengan usia dewasa. Oleh karena itu diperlukan suatu tindakan pencegahan untuk meminimalkan lanjut usia terinfeksi COVID-19. Vaksinasi merupakan salah satu tindakan pencegahan yang dapat dilakukan pada kelompok umur lanjut usia.

Angka kematian pada lanjut usia usia 60 tahun ke atas akibat COVID-19 mencapai 49.4 persen dan menjadi yang tertinggi di antara kelompok usia lainnya. Tingginya risiko pada kelompok lanjut usia menjadi penting untuk memprioritaskan perlindungan kepada lanjut usia. Berdasarkan data diketahui kelompok usia 46-59 tahun mencapai 35.5 persen, usia 31-45 tahun sebanyak 11.2 persen, sisanya berasal dari kelompok usia 30 tahun ke bawah. Sampai saat ini total kematian lanjut usia akibat terinfeksi COVID-19 sebanyak 50.100 jiwa (Kementerian Kesehatan Republik Indonesia, 2019). Dilain pihak, ada perubahan dalam peran keluarga dalam merawat lanjut usia sebagi akibat globalisasi. Meningkatnya pekerja usia produktif untuk mencari nafkah sehingga banyak anak yang meninggalkan orang tua di rumah bahkan ada yang mengirim ke panti werdha karena tidak punya waktu untuk mendampingi dan merawat lanjut usia (Ezalina et al., 2019;Ezalina et al., 2021). Saat ini, jumlah lanjut usia yang tinggal di panti 872 orang, lanjut usia yang tinggal sendiri di pedesaan 10.10 persen, dan tinggal di perkotaan 8.74 persen. Data lanjut usia di tinjau dari tempat tinggal didapatkan yang tinggal bersama pasangan 20.03 persen, tinggal dengan keluarga 27.03 persen, tinggal dengan tiga generasi 40.64 persen, dan lanjut usia yang tinggal sendiri sebanyak 9.38 persen. Untuk kondisi kesehatan lanjut usia menunjukkan 51.08 persen mengalami keluhan kesehatan dengan angka kesakitan 26.20 persen dan sebanyak 1400 lanjut usia tidak memiliki Kartu Jaminan Kesehatan Nasional. Menurut Badan Pusat Statistik 2019 dari seluruh lanjut usia yang ada di Indonesia, lanjut usia muda (60-69 tahun) sebanyak 63.82 persen, selanjutnya diikuti lanjut usia madya (70-79 tahun) sebanyak 27.68 persen, dan lanjut usia tua (80 tahun) sebesar 8.5 persen (Badan Pusat Statistik, 2019). Hal ini akan mempengaruhi kondisi kesehatan lanjut usia dalam menjalani aktifitas dan kehidupan masa tuanya. Pada kondisi bencana termasuk pandemic COVID-19 yang melanda dunia dalam jangka waktu lama akan berdampak pada lanjut usia. Dimana, lanjut usia yang hidup sendiri menjadi berisiko tinggi akibat terbatasnya sumber daya yang dimiliki (Anderson et al., 2020).

Tingginya prevalensi dan dampak yang ditimbulkan pandemic COVID-19 secara tidak langsung menjadi masalah kesehatan fisik dan kesehatan mental pada lanjut usia dan memerlukan upaya khusus untuk mengatasi masalah tersebut. Upaya penanganan masalah kesehatan fisik dapat dilaksanakan dengan mengkonsumsi makan yang bergizi sesuai kecukupan lanjut usia (Wilianarti, 2018). Upaya penanganan kesehatan mental dapat dilakukan secara efektif apabila upaya tersebut dapat mengatasi faktor-faktor yang berhubungan dengan gangguan kesehatan mental pada lanjut usia salah satunya rasa cemas yang berlebihan. Kondisi Pandemi akan mengakibatkan kecemasan pada lanjut usia. Kecemasan pada lanjut usia dapat disebabkan oleh karena lanjut usia tidak memahami kejadian dan penangulangan penularann COVID-19, serta pencegahan yang dapat dilakukan agar lanjut usia terhindar dari terjangkitnya COVID-19. Sedang kecemasan merupakan salah satu leading faktor menurunnya system imunitas seseorang dengan meningkatnya jumlah faktor-faktor inflamasi melaui HPA axis (Lamontagne et al., 2020). Pada review literatur ditemukan bahwa kecemasan mempunyai dampak pada perubahan kadar protein C-reaktif perifer (CRP) (Valkanova et al., 2013), Jumlah sel darah putih (WBC) (Shafifiee et al., 2017) dan sitokin yang berlebihan (Köhler et al., 2017) (Guo et al., 2020). Sehingga meningkatkan angka morbiditas dan mortalitas kelompok lanjut usia (Lamontagne et al., 2020).

Upaya Pemerintah dalam mengatasi pandemic pada kelompok resiko yaitu kelompok lanjut usia dengan memberikan upaya preventif yaitu pemberian vaksinasi COVID-19. Pemberian vaksinasi COVID-19 pada kelompok lanjut usia diketahui banyak menimbulkan pendapat dan persepsi yang salah pada kelompok masyarakat. Khususnya lanjut usia yang merupakan kelompok resiko tinggi terhadap penularan COVID-19 (Morrowhowell et al., 2020). Karakteristik lanjut usia yang berbeda menjadi sebuah masalah yang harus di selesaikan. Kelompok lanjut usia cenderung menginginkan kenyamanan dalam pelayanan kesehatan. Selain itu kenyamanan kondisi karena bisa bersama-sama dengan rekan sebaya mereka. Oleh karena hal tersebut diatas sangat dibutuhkan sosialisasi kepada lanjut usia yang dilakukan oleh tenaga kesehatan dengan bantuan kader kesehatan 
sehingga cakupan vaksinasi COVID-19 dapat terpenuhi.

\section{METODE}

Metode kegiatan dari kegiatan pengabdian masyarakat ini adalah dengan menggunakan metode pendampingan, penyuluhan menggunakan peer group. Adapun pelaksanaan pengabdian dilaksanakan dengan beberapa tahap yaitu:

\section{Tahap I. Persiapan}

a. Identifikasi analisis kebutuhan Kelompok Kader Di Wilayah Mulyorejo Surabaya.

b. Menentukan metode penyuluhan dengan peer group.

c. Melakukan pre test pada kader kesehatan untuk mengetahui pengetahuan kader tentang penularan COVID-19, Pencegahan COVID-19 dan Pentingnya Vaksinasi bagi Lanjut Usia

\section{Tahap II. Pelaksanaan}

a. Membentuk kelompok kecil dan memilih ketua group. Ketua group adalah kader kesehatan sedangkan anggota group adalah para lanjut usia yang dinilai mempunyai kemampuan untuk memotivasi teman sesame lanjut usianya. Adapun pelaksanaan group kecil sejumlah 7 group dalam 1 group terdiri dari 10-12 lanjut usia

b. Narasumber menyampaikan materi kepada coordinator kader pada tiap RW mengenai penularan COVID-19, Pencegahan COVID19 dan Pentingnya Vaksinasi bagi Lanjut Usia

c. Pembagian Leaflet sebagai media Penyuluhan.

d. Demonstrasi cara menggunakan Masker dan cuci tangan yang benar.

\section{Tahap III. Evaluasi}

a. Setelah selesai semua kegiatan akan diadakan post test untuk mengetahui sejauh mana peningkatan pengetahuan pada kader kesehatan di wilayah Mulyorejo.

b. Masing-masing kader melakukan motivasi kepada lanjut usia sesuai wilayah untuk mengikuti vaksinasi COVID-19 di Puskesmas.

\section{HASIL DAN PEMBAHASAN}

Tahap persiapan, survei lapangan ini bertujuan untuk megetahui secara langsung jumlah kader lanjut usia yang menjadi target sasaran, usia, dan kesiapan tim Pengabdian Kepada Masyarakat (PKM). Kemudian ketua tim pelaksana PKM mengurus proses perizinan kepada Bakesbanglinmas kota Surabaya, dan dinas kesehatan kota untuk mendapatkan ijin pengabdian masyarakat. Selanjutnya menetukan waktu yang tepat untuk melakukan kegiatan pengabdian masyarakat, serta bahan dan alat yang dibutuhkan untuk kegiatan sosialisasi.

Kegiatan pengabdian pada masyarakat ini dilaksanakan di Puskesmas Mulyorejo. Peserta dalam PKM ini adalah kader kesehatan sejumlah 15 orang kader. Usia rata rata para kader adalah berkisar 45 tahun sampai dengan 56 tahun. Pendidikan kader bervariasi yaitu 55 persen berpendidikan SMA orang 45 persen berpendidikan Sarjana dan sebagian kecil SMP.

Berdasarkan hasil identifikasi diketahui bahwa 35 persen kader menyatakan belum memahami secara jelas tentang pentingnya vaksinasi COVID-19 untuk kelompok resiko tinggi. Selanjutnya pelaksanaan kegiatan tahap pertama adalah pelaksanaan pre-test yang bertujuan untuk mengetahui sejauh mana tingkat pengetahuan kader terhadap pengenalan vaksinasi, daya tahan tubuh selama pandemic Rata-rata nilai pretest pengetahuan kader mengenai vaksinasi $<55$ sebanyak 12 kader, sedangkan 2 orang hanya 13,3 persen kader yang mempunyai nilai skor diatas $\geq 56$ - 75 . Dari jumlah soal pre-test yang diberikan hanya sebagian yang dapat dijawab benar oleh para kader. Hal ini menandakan bahwa tingkat pengetahuan kader mengenai pentingnya vaksinasi pada lanjut usia masih cukup rendah.

Tahap ke dua yaitu tahap pelaksanaan, melakukan membentuk kelompok kecil dan menentukan coordinator group. Koordinator kader bertugas untuk mengkoordinasikan pelaksanaan vaksinasi dan memberikan informasi tentang penjelasan vaksin, menyampaikan leaflet pada anggota kader. Selanjutnya menugaskan anggota kader untuk mensosialisasikan melalui aktifitas kunjungan rumah pada kelompok resiko tinggi atau yang mempunya anggota keluarga yang berusia 56 tahun keatas. Materi yang diberikan selama kegiatan adalah mengenai definisi vaksinasi, alur pelaksanaan, hal-hal yang dilakukan setelah vaksinasi. Selama memberikan penyuluhan, pemateri juga melakukan tanya jawab kepada peserta. Ketika kader diberikan pengetahuan, maka mereka akan menyerap dengan cepat materi yang diberikan. Sehingga pendidikan kesehatan harus terus menerus diberikan dengan harapan dengan semakin meningkatnya pengetahuan peserta, maka akan dapat mengubah sikap dan perilaku mereka dalam agar mempunyai kesadaran untuk melakukan vaksinasi. Gambar 1. Merupakan media yang digunakan sosilalisasi pada kader dengan menggunakan metode peer 
group. Adapun materi ini diberiakan sesetah dilakukan pre test.
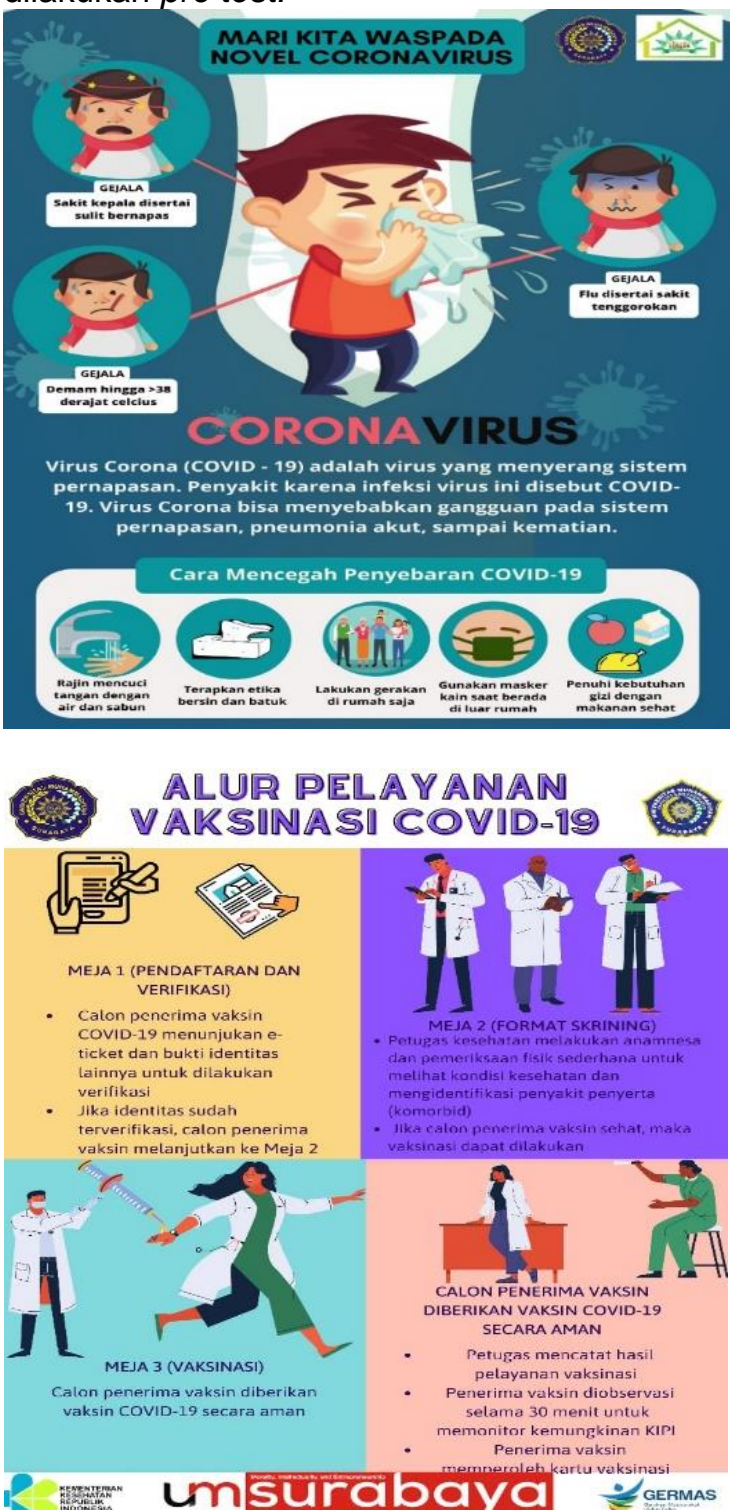

Gambar 1. Media PKM dalam Pemberian Materi

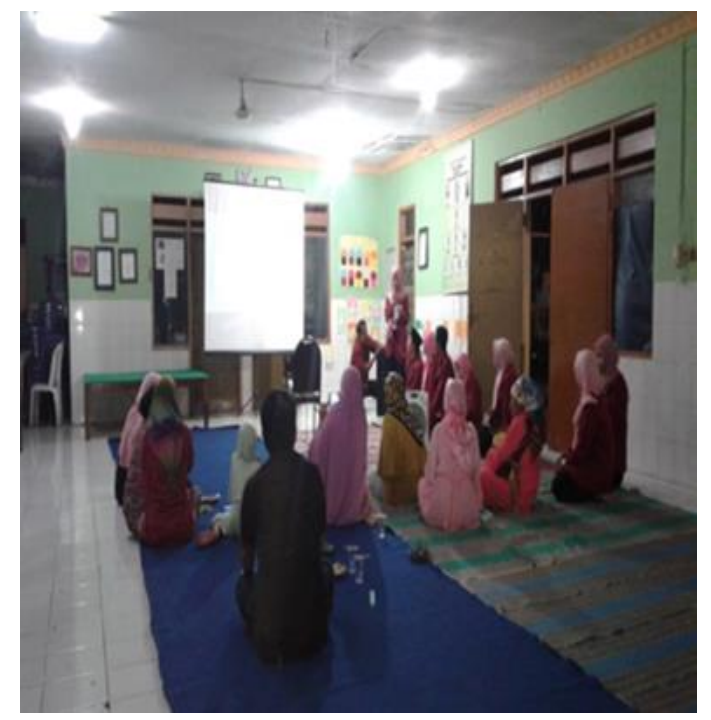

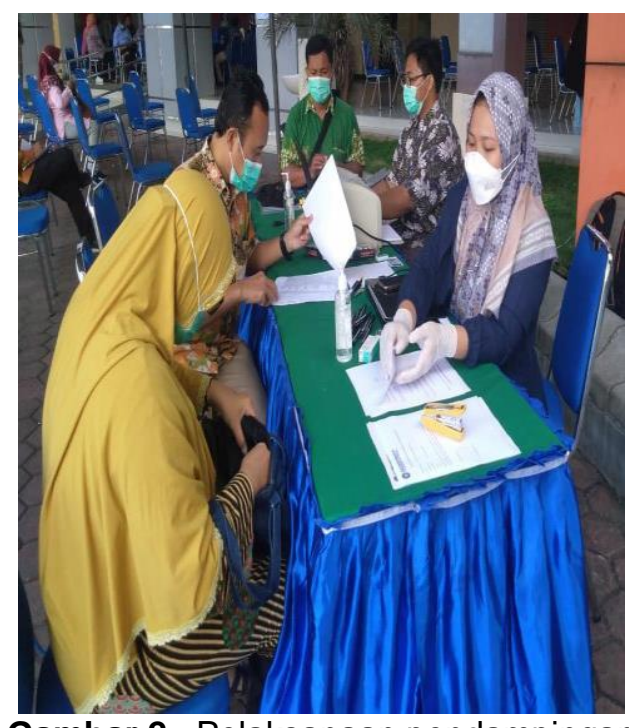

Gambar 2. Pelaksanaan pendampingan kader dan pelaksaan sosialisasi

Koordinator kader menjelaskan kepada para lanjut usia secara berkelompok dengan jadwal yang telah di tentukan oleh tiap kelompok.

Kegiatan tahap ketiga atau tahap evaluasi adalah pelaksanaan Post Test yang bertujuan untuk mengetahui sejauh mana peningkatan pengetahuan kader terhadap pengenalan vaksinasi Rata-rata nilai post test pengetahuan 10 orang 67 persen yang mempunyai nilai skor $\geq 56-75$ alah 5 orang yaitu 33 persen. Dari nilai skor post test yang diberikan terdapat peningkatan nilai sebagian besar kader memiliki nilai skor $\geq 75$ pada kegiatan post-tes. Hal ini dapat dikatakan bahwa kegiatan penyuluhan ini cukup berhasil dalam pengetahuan kader.

Tahap akhir pelaksanaan kegiatan dilakukan melalui evaluasi terhadap materi yang sudah disampaikan dengan menggunakan kuesioner dengan jumlah 10 pertanyaan dengan alternatif jawaban Benar (B) dan Salah (S) dengan bahasa yang mudah dipahami. Tahap akhir pelaksanaan kegiatan diakhiri dengan dokumentasi dan wawancara dengan para kader lanjut usia terhadap kegiatan dan aktivitas kader dalam melakukan sosialisasi tentang pentingnya vaksinasi COVID-19.

Setelah dilakukan sosialisasi vaksinasi dilingkungan Puskesmas Mulyorejo mulai RW 1 sd RW 4. Diketahui bahwa terdapat peningkatan cakupan vaksinasi lanjut usia dalam melakukan kunjungan untuk vaksin. Pelaksanan sosialisasi dapat dilakukan dengan mengumpulkan kader kesehatan masing masing RW di wilayah Puskesmas Mulyorejo.

Pelaksanaan pengabdian masyarakat yang dilakukan bersama mahasiswa di wilayah Puskesmas Mulyoreja dilakukan dalam bentuk 
kegiatan penyuluhan menggunakan metode peer group. Adapun pelaksanaan group kecil sejumlah 7 group dalam 1 group terdiri dari 1012 lanjut usia. Pada tahap pertama dilaksanakan identifikasi masalah ditemukan lanjut usia belum mengerti tentang manfaat vaksin dan merasa ragu untuk melakukan vaksin, yang kemudian menjadi dasar pelaksanaan pengabdian. Pada tahap selanjutnya untuk membentuk peer group sebagai metode lanjut usia yang ada didampingi oleh keluarga saaat menerima penjelasan dari coordinator group, dan kemudian dilakukan pre test.

Hasil pre-test didapatkan bahwa sebagian besar kader memiliki pengetahuan yang kurang tentang vaksinasi dan kesehatan lanjut usia dimasa pandemi. Pengetahuan seseorang sangat dipengaruhi oleh usia, pengalaman, pendidikan dan akses sumber informasi. Media sosial telah menjadi salah satu media untuk edukasi dimulai dari banyaknya informasi dan peluang terjadinya interaksi serta arahan untuk menuju pengembangan informasi ke dalam tautan lain. Hal tersebut menandakan bahwa selain keterkaitannya sebagai media hiburan, media sosial dapat dijadikan sebagai alternatif sumber jawaban untuk pertanyaan keseharian, termasuk info dan pertanyaan tentang COVID-19 (Tejo et al., 2020). Menurut Notoatmojo (2010) bahwa pendidikan kesehatan sebagai bagian dari kesehatan masyarakat berfungsi sebagai media atau sarana untuk menyediakan kondisi sosiopsikologis sedemikian rupa sehingga individu atau masyarakat berperilaku sesuai dengan norma-norma hidup sehat (Notoatmodjo, 2012). Dengan perkataan lain pendidikan kesehatan bertujuan untuk merubah perilaku individu atau masyarakat sehingga sesuai dengan normanorma hidup sehat. Pada kondisi pandemic COVID-19-19 perlu dilakukan promosi kesehatan sehingga perilaku pencegahan tetap bisa dijalankan sesuai dengan protocol kesehatan. Upaya peningkatan kesehatan pada masyarakat pada masa pandemic bertujuan mengubah perilaku individu, keluarga dan masyarakat untuk melaksanakan pencegahan penyakit. Sebuah penyakit dapat digambarkan sebagai gangguan tertentu yang dapat dicegah oleh tindakan kesehatan. Namun perlu diperhatikan bahwa setiap penyakit memiliki tindakan yang berbeda. Hal ini juga dapat di jelaskan dalam pencegahan penyebaran penyakit COVID-19-19 bahwa penyebaran penyakit ini dapat dilakukan pencegahan yang tentunya bersumber pada perilaku individu, keluarga dan Masyarakat. Berdasarkan uraian diatas bahwasanya selain pencegahan dalam bentuk pemberian vaksin pada kelompok resiko bahwasanya Pencegahan dengan memperbaiki perilaku kesehatan dengan menggunakan Masker, menjaga Jarak dan mencuci tangan sangat dibutuhkan dalam mengatasi pandemi ini.

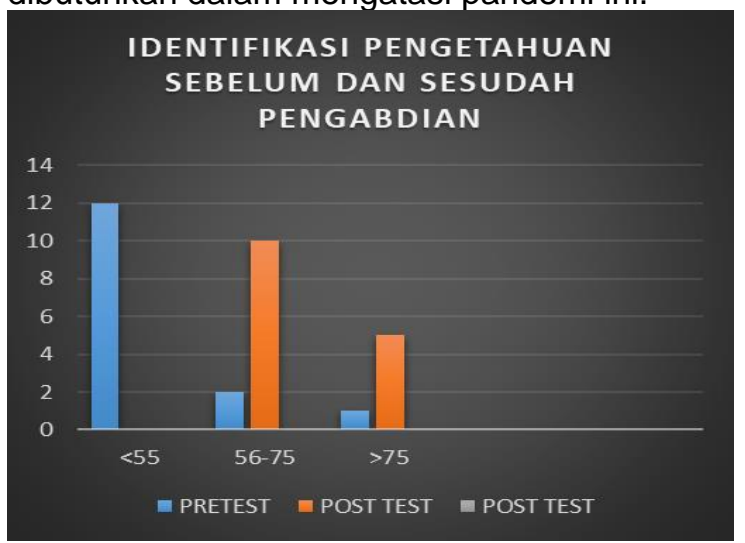

Gambar 3. Identifikasi Pengetahuan sebelum dan sesudah Pengabdian

Optimalisasi metode peer group dalam peningkatan cakupan vaksinasi ini dapat diketahui dari terjadinya peningkatan jumlah lanjut usia yang bersedia untuk mengikuti kegiatan vaksinasi yaitu $85 \%$. Menurut Arjanggi dan Suprihatin metode tutor sebaya adalah suatu metode pembelajaran yang dilakukan dengan cara memberdayakan individu yang memiliki daya serap yang tinggi dari kelompok tertentu untuk menjadi tutor bagi teman temannya, dimana personal yang menjadi tutor bertugas untuk memberikan materi belajar dan latihan kepada teman-temannya (tutee) yang belum faham terhadap materi/ yang diberikan fasilitator dengan berdasarkan pada aturan yang telah disepakati bersama dalam kelompok tersebut, sehingga akan terbangun suasana proses dalam kelompok yang bersifat kooperatif bukan kompetitif (Arjanggi \& Suprihatin, 2010). Dalam kelompok dengan metode Peer group mengalami peningkatan pengetahuan namun tidak terlalu banyak, responden yang mayoritas masih remaja tidak dapat melakukan pembelajaran tanpa pendampingan langsung. Dalam Peer group tutor dilakukan oleh teman sebaya atau teman yang memiliki kemampuan komunikasi dan pemahaman suatu materi.

Dalam kelompok dengan metode Peer group mengalami peningkatan pengetahuan namun tidak terlalu banyak, responden yang mayoritas masih remaja tidak dapat melakukan pembelajaran tanpa pendampingan langsung. Dalam Peer group tutor dilakukan oleh teman sendiri. Padahal diketahui dari karakteristik responden pada kelompok Peer group Peer paling banyak berumur 13 tahun sebanyak 48 orang (85,7 persen). Sehingga dapat diasumsikan bahwa para responden belum 
memiliki pengalaman. Hal ini sesuai dengan teori Notoadmojo (2012) Pengalaman sebagai sumber adalah suatu cara untuk memperoleh kebenaran pengetahuan dengan cara mengulang kembali pengetahuan yang diperoleh dalam memecahkan masalah yang dihadapi masa lalu. Dalam hal ini pengalaman menjadi faktor kendala peningkatan pengetahuan tidak sebanyak dengan metode audio visual. Ketika tutor memberikan penjelasan pada tutee, tutor melakukan pengintegrasian konsep dan prinsip serta memunculkan ide baru. Selain itu, ketika tutee mengajukan pertanyaan yang spesifik dan mendalam, hal itu akan mendukung tutee dalam merefleksikan pengembangan pengetahuan, dimana tutor berperan membantu proses ini sekaligus juga menguatkan pemahamannya.

Peran kader adalah memberikan sosialisasi dengan metode yang effektif. Melalui kegiatan pengabdian diharapkan lanjut usia dapat mempraktikkan ilmu yang sudah diperoleh melalui kemandirian dan kewaspadaan dalam menghadapi pandemi virus corona sehingga lanjut usia tetap sehat dan bisa beraktifitas secara normal tanpa ada hambatan dan ketakutan (Ezalina et al., 2021). Proses penyampaian berita baru pada masyarakat tidak mudah untuk diterima. Masyarakat memiliki kemampuan dalam menerima sebuah perubahan atau informasi baru. Perubahan dalam masyarakat sebagian besar disebabkan oleh bagaimana informasi ditransmisikan, dengan orang-orang yang selalu terhubung dan terusmenerus mendapat informasi tentang apa yang terjadi dalam kehidupan seseorang atau apa yang terjadi di seluruh dunia. Hal ini juga berlaku informasi tentang COVID-19 ini. Beraneka ragam informasi yang diterima oleh masyarakat dan tidak semua informasi tersebut benar. Untuk itu dengan adanya Kader kesehatan yang berperan dalam pemberian menyuluhan COVID-19 diharapkan dapat memberikan informasi yang benar.

Pada dasarnya bukan hal yang mudah untuk memutuskan bahwa kelompok usia tua sebagai prioritas pemberian vaksin COVID-19 di suatu negara. Ada beberapa pertimbangan penentu kebijakan publik. karena sebagian cukup besar kasus COVID-19-19 yang berat dan meninggal- adalah pada usia tua maka kalau mereka diberi vaksin yang memproteksinya maka akan sangat berpengaruh pada pola epidemiologi angka kematian dan keadaan sakit berat (Aditama, 2020; Garg et al., 2020).

Akibat dari pandemi ini, pemerintah mengimbau masyarakat untuk melakukan kegiatan dari rumah, seperti bekerja, beribadah dan sekolah, dan mengurangi aktivitas yang melibatkan banyak orang sehingga mempengaruhi mobilitas masyarakat untuk bepergian keluar rumah. Pelaksanaan imunisasi dasar yang seharusnya rutin dilakukan di fasilitas kesehatan merupakan salah satu komponen yang terkena dampaknya. Meskipun dalam kondisi pandemi COVID-19-19, program imunisasi harus dilaksanakan seperti telah tertera pada panduan imunisasi dari Kementerian Kesehatan RI dan Ikatan Dokter Anak Indonesia (Irawati, 2020).

\section{SIMPULAN DAN SARAN}

Dari hasil pengabdian yang telah dilakukan dapat disimpulkan bahwa terdapat peningkatan pengetahuan mengenai pentingnya vaksinasi pada lanjut usia yaitu memililiki pengetahuan cukup. Metode peergroup efektif dalam pemberian informasi atau pengetahuan tentang Pentingnya vaksinasi pada kelompok resiko tinggi yaitu lanjut usia. Sehingga dibutuhkan kerjasama lintas program dan sectoral ddalam meningkatkan cakupan Vaksinasi sebagai upaya preventif dan meningkatkan kesehatan masyarakat secara menyeluruh. Penyuluhan secara berkala pada lanjut usia mengenai menjaga status kesehatan lanjut usia agar lanjut usia tetap sehat dan bugar selama Pandemi

\section{UCAPAN TERIMAKASIH}

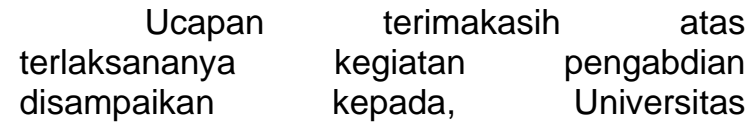
Muhammadiyah Surabaya melalui LPPM Fakultas IImu Kesehatan, Dinas Kesehatan Kota Surabaya, Kepala Puskesmas Mulyorejo Kecamatan Mulyorejo

\section{DAFTAR RUJUKAN}

Aditama, T. Y. (2020). Covid-19 dalam Tulisan Prof.Tjandra. Lembaga Penerbit Badan Penelitian dan Pengembangan.

Anderson, M., McKee, M., \& Mossialos, E. (2020). Covid-19 exposes weaknesses in European response to outbreaks. The $B M J$, 368(April). https://doi.org/https://doi.org/10.1136/bmj. m1075

Arjanggi, \& Suprihatin. (2010). Metode Pembelajaran Tutor Teman Sebaya Meningkatkan Hasil Belajar Berdasar Regulasi diri. Jurnal Fakultas Psikologi Islam Sultan Agung (Unissula) Semarang, 14(2).

Ezalina, Deswinda, \& Erlin, F. (2021). EDUKASI 
PENCEGAHAN COVID-19 BAGI LANSIA PANTI JOMPO HUSNUL KHOTIMAH PEKANBARU. Jurnal Masyarakat Mandiri, $\quad$ 5(1). https://doi.org/https://doi.org/10.31764/jm m.v5i1.3820

Ezalina, E., Machmud, R., Effendi, N., \& Maputra, Y. (2019). Effectiveness of the elderly caring model as an intervention to prevent the neglect of the elderly in the family. Open Access Macedonian Journal of Medical Sciences, 1(14), 2365- 2370. https://doi.org/https://doi.org/10.3889/oa mjms.2019.650

Garg, S., Kim, L., Whitaker, M., O'Halloran, A., Cummings, C., Holstein, R., Prill, M., Chai, S. J., Kirley, P. D., Alden, N. B., Kawasaki, B., \& Kimbe, M. (2020). Morbidity and Mortality Weekly Report (MMWR): Hospitalization Rates and Characteristics of Patients Hospitalized with LaboratoryConfirmed Coronavirus Disease 2019 COVID-NET, 14 States, March 1-30, 2020.

Guo, Q., Zheng, Y., Shi, J., Wang, J., Li, G., \& $\mathrm{Li}$, C. (2020). Immediate psychological distress in quarantined patients with COVID-19 and its association with peripheral inflammation: A mixed-method study. Brain, Behavior, and Immunity, 88(January), 17-27.

Indarwati, R. (2020). Lindungi Lansia dari Covid-19. Jurnal Keperawatan Komunitas, 5(1).

Indonesia, K. K. R. (2019). Analisis lanjut usia di Indonesia. Pusat Data dan Informasi Kementrian Kesehatan Republik Indonesia.

Irawati, N. A. V. (2020). Imunisasi Dasar dalam Masa Pandemi COVID-19. JK Unila, 4(2).

Lamontagne, S. J., Pizzagalli, D. A., \& Olmstead, M. C. (2020). Does inflammation link stress to poor COVID-19 outcome.pdf (pp. 1-14).

Morrow-howell, N., Galucia, N., \& Swinford, E. (2020). Recovering from the COVID-19 Pandemic: A Focus on Older Adults Recovering from the COVID-19 Pandemic: A Focus on Older Adults. Journal of Aging \& Social Policy, 32(4-5), 526-535.

https://doi.org/10.1080/08959420.2020.1 759758

Notoatmodjo. (2012). Pendidikan Dan Perilaku Kesehatan. Rineka Cipta.

Organization, W. H., \& Control, C. for D. (2020). Lindungi Lanjut Usia Dalam Perseteruan Manusia VS COVID-19. https://transindonesia.co/2020/03\%0A/lin dungi-lanjut-usia-dalam\%02perseteruan-
manusia-vs-COVID-\%0A19.2020, diakses 21 Mei 2020

Statistik, B. P. (2019). Profil Statistik Kesehatan.

Tejo, M. B. S., Kusumandyoko, T. C., \& Islam, M. A. (2020). Budaya Media Sosial, Edukasi Masyarakat dan Pandemi COVID-19. Jurnal Sosial \& Budaya SyarI, 7(6).

Wilianarti, P. F. (2018). Nutrition and Diet Textbook.UMSurabaya Press 